\title{
Transfer of elements to owls (Tyto Alba, Strix Aluco) determined using neutron activation and gamma analysis
}

\author{
C.L. Barnett ${ }^{1}$, B.J. Howard ${ }^{1}$, D.H. Oughton ${ }^{2}$, C. Coutris ${ }^{2}$, E.D. Potter ${ }^{1}$, \\ T. Franklin ${ }^{1}$, L.A. Walker ${ }^{1}$ and C. Wells ${ }^{1}$ \\ ${ }^{1}$ Centre for Ecology \& Hydrology, Lancaster Environment Centre, Library Avenue, Bailrigg, \\ Lancaster, LA1 4AP, UK \\ e-mail: clb@ceh.ac.uk \\ ${ }^{2}$ Norwegian University of Life Sciences (UMB), P.O. Box 5003, NO-1432, Ås. Norway
}

\begin{abstract}
The IAEA is currently preparing a new Technical Reports Series (TRS) Handbook on the Transfer of Radionuclides to Wildlife. Key deficiencies have been identified and one is the lack of data for birds. In this study we measured the transfer of a range of elements measured by neutron activation analysis (NAA) and gamma analysis in four Barn owls (Tyto alba) and one Tawny owl (Strix aluco) from archived samples available from the Predatory Bird Monitoring Scheme, http://pbms.ceh.ac.uk. Transfer was quantified as the whole organism concentration ratio $\left(C R_{\text {wo-soil }}\right)$ and values for $\mathrm{Co}, \mathrm{Fe}, \mathrm{Rb}, \mathrm{Sc}, \mathrm{Zn}$ and ${ }^{137} \mathrm{Cs}$ are presented. The work demonstrates the potential for existing sample archives to be exploited for radioecological purposes. They represent a cost effective means to derive $\mathrm{CR}_{\mathrm{wo} \text {-media }}$ values for organismradionuclide combinations relevant to radiological assessments without the requirement of field sampling.
\end{abstract}

\section{INTRODUCTION}

The International Atomic Energy Agency (IAEA) has recently collated data for a handbook on transfer of radionuclides to wildlife (pending publication as a Technical Reports Series (TRS) document, see [1]). During this process, key data deficiencies were identified, one of which is the lack of data on the transfer of many elements for birds. The majority of the available data for radionuclides are for game species (e.g. Lagopus spp.) and small song birds. The aim of this study was to consider the feasibility of using a predatory bird sample archive to derive whole organism concentration ratio $\left(\mathrm{CR}_{\mathrm{wo}-\text { soil }}\right)$ values, as used by the IAEA, for owls for a range of elements relevant to radiological assessments. The $\mathrm{CR}_{\mathrm{wo} \text {-soil }}$ is defined as the ratio between the concentration of an element/radionuclide in owls (whole organism), measured in $\mathrm{Bq} \mathrm{kg}^{-1}$ or $\mathrm{mg} \mathrm{kg}^{-1}$ fresh weight (fw) and the concentration of the same element/radionuclide in soil, measured in $\mathrm{Bq} \mathrm{kg}^{-1}$ or $\mathrm{mg} \mathrm{kg}^{-1}$ dry weight (dw).

The Barn (Tyto alba) and Tawny (Strix aluco) owls were selected as examples of a widespread, terrestrial, predatory bird for which archived samples from 2008 were available from the Predatory Bird Monitoring Scheme (PBMS). Their predominant habitats are rough grassland, field and watercourse 'edges', and grass strips alongside woods. They have an average home range of approximately $3 \mathrm{~km}^{2}$ and their diet is predominantly rodents (especially voles) and small birds [2]. The PBMS scheme (http://pbms.ceh.ac.uk/) is a long-term (1970 onwards), large scale project which holds a sample archive of 32000 tissues and eggs of predatory birds from throughout the UK. Its aim is to quantify accumulation of contaminants and their effects in predatory birds. The birds submitted to the project have been found dead, usually from road accidents. 


\section{METHODOLOGY}

\subsection{Sampling}

Four Barn owls (two adults and two unfledged chicks) and one adult Tawny owl were selected for analysis from archived samples submitted to the Predatory Bird Monitoring Scheme between MarchJuly 2008. The birds were all found within an area of approximately $25 \mathrm{~km}^{2}$ from Malltraeth Marsh, East Anglesey, Wales (national grid reference: SH460720) which is a Site of Special Scientific Interest. Five soil samples about $1.5 \mathrm{~m}$ apart and $10 \mathrm{~cm}$ deep were collected in April 2009 from the vicinity of each of the recorded collection sites giving a total of 20 soil samples.

\subsection{Sample preparation}

All birds were stored frozen $\left(-20^{\circ} \mathrm{C}\right)$ prior to sample preparation. After defrosting, the birds were plucked and had their gastrointestinal tract removed. The livers were then removed and weighed fresh (range 5-8g). They were then analysed fresh for gamma emitting radionuclides prior to being ashed slowly to $400^{\circ} \mathrm{C}$ and reweighed. The remaining carcasses were weighed (range 105-303 g) and then ashed at $450^{\circ} \mathrm{C}$ and reweighed. All soil samples were oven dried at $60^{\circ} \mathrm{C}$ soon after collection. Once dry and homogenised, $50 \mathrm{~g}$ was sub-sampled and ashed at $450^{\circ} \mathrm{C}$ and then reweighed for neutron activation analysis (NAA). The remaining oven dry sample was analysed for gamma emitting radionuclides.

\subsection{Analytical methods}

\subsubsection{Gamma analysis}

Samples were analysed by gamma spectrometry on hyper-pure germanium detectors to determine gamma emitting radionuclide concentrations. The detectors are calibrated for efficiency using a mixed radionuclide standard which covers an energy range of approximately $59-1850 \mathrm{keV}$ for a number of matrix/geometry combinations. Prior to submission for Neutron Activation Analysis, ashed owl carcasses and fresh liver were analysed in $25 \mathrm{ml}$ petri dishes and the oven dried, homogenised, soil samples were analysed in $150 \mathrm{ml}$ counting containers. The count time for all sample types was up to 4 days. Spectra were analysed using the Canberra Apex-Gamma software for photopeak identification and subsequent quantification.

\subsubsection{Neutron activation analysis}

Ashed carcass, liver, soil samples and certified reference materials were weighed into polyethylene vials, heat sealed and submitted to neutron activation at a flux of $10^{12}$ neutrons $\mathrm{cm}^{-2} \mathrm{~s}^{-1}$ for 1 day at the reactor of the Institute of Energy Technology (Kjeller, Norway). Certified reference materials included ashed pig kidney (BCR186), dried soil (GBW07405), peach leaves (SRM1547), pine needles (SRM1575) and evaporated liquid multi-element standards. Three replicates were included for each reference material. Following activation all samples were counted for gamma emitting radionuclides three times: the first count after approximately one week to obtain short-lived activation products; the second after 3-4 weeks, and finally after 3-4 months which allows for a more sensitive determination of long-lived activation products following decay of short-lived products (more information on the method can be found in [3].

Conversion factors from $\mathrm{Bq}$ to $\mathrm{mg}$ were calculated from the different reference materials. In most cases, the variability in conversion factors was less than the counting error for the individual activation products. Likewise, for those elements giving results at repeat count times, the variation between counts was usually less than the counting errors. The count giving the lowest counting error was identified for each element, and this was used consistently across all samples. In all calculations, the errors on 


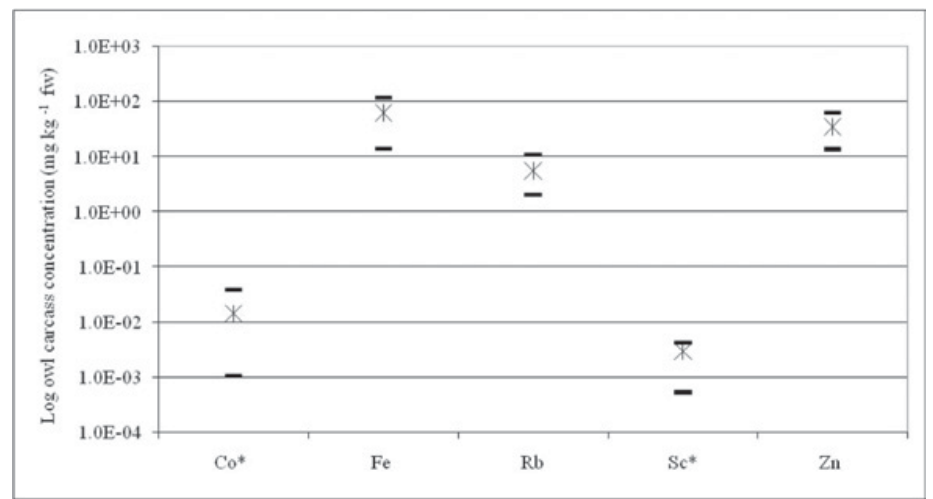

Figure 1. Arithmetic mean, minimum and maximum element concentrations in the five owl carcasses. *Co and Sc include two values below detection limits (they have been halved prior to calculation of the mean).

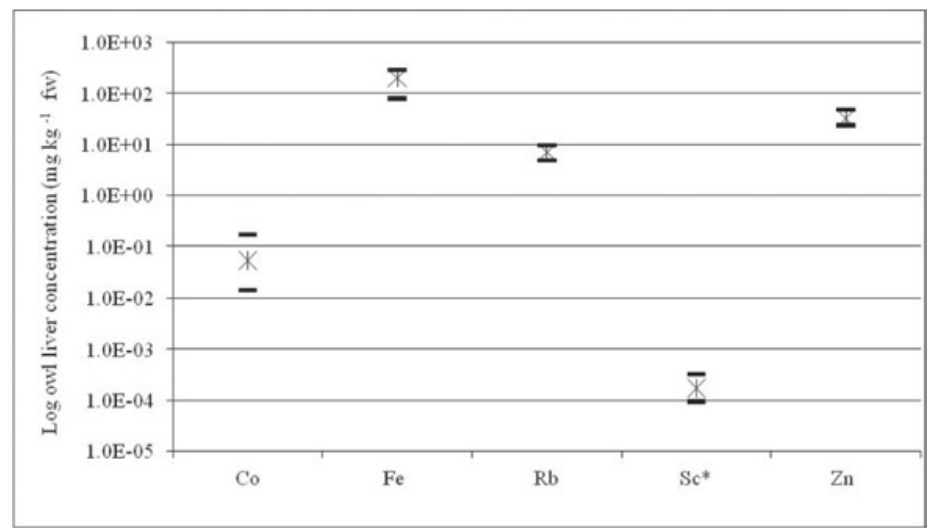

Figure 2. Arithmetic mean, minimum and maximum element concentrations in the five owl livers. ${ }^{*} \mathrm{Sc}$ includes three values below detection limits (these values have been halved prior to calculation of the mean).

conversion factors, counting errors and (where averages were taken) errors on sample variability were taken into account when estimating total uncertainties for each analysis.

\section{RESULTS \& DISCUSSION}

\subsection{Neutron activation analysis}

The mean concentrations of $\mathrm{Co}, \mathrm{Fe}, \mathrm{Rb}, \mathrm{Sc}$ and $\mathrm{Zn}$ were measured in the liver and carcasses of both species and all ages of owl are shown in Figures 1 and 2 (other elements were undetectable in the majority of samples in these tissues). Where individual measurements for a particular element/tissue combination were below detection limits, a value of $50 \%$ of the detection limit was used to calculate the mean (see Figures 1 and 2). Concentrations of $\mathrm{Co}, \mathrm{Fe}, \mathrm{Rb}, \mathrm{Sc}$ and $\mathrm{Zn}$ in soils are given in Table 1. The element concentrations were converted from ash to fresh weight (fw) for birds and ash to dry weight (dw) for soils using the individual data for each sample. The ratio of ash to fresh weight ratio ranged from $0.055-0.064$ for the carcass and $0.009-0.0014$ for liver. The ratio of ash to dry weight for the soils ranged from $0.84-0.94$. For owl samples, counting errors for neutron activation products were less than $15 \%$ except for Co in liver which was $<25 \%$. 
Table 1. Element concentrations $\left(\mathrm{mg} \mathrm{kg}^{-1} \mathrm{dw}\right)$ in the soil samples.

\begin{tabular}{|l|c|c|c|}
\hline Element & \multirow{2}{*}{} & \multicolumn{2}{|c|}{ Concentration $\mathbf{~ m g ~ k g}^{-1}(\mathbf{d w})$} \\
\cline { 3 - 4 } & & Mean & SD \\
\hline $\mathrm{Co}$ & 20 & $13^{\wedge}$ & 1.6 \\
\hline $\mathrm{Fe}$ & 20 & 30000 & 2670 \\
\hline $\mathrm{Rb}$ & 20 & 58 & 16 \\
\hline $\mathrm{Sc}$ & 20 & $11^{\wedge}$ & 1.4 \\
\hline $\mathrm{Zn}$ & 20 & 150 & 54 \\
\hline
\end{tabular}

$\wedge$ Counting error between $15-30 \%$

Table 2. $\mathrm{CR}_{\mathrm{wo}-\text { soil }}$ values measured in this study (whole body (fw)) compared with ERICA Tool $\mathrm{CR}_{\mathrm{wo}-\text { soil values }}$ where data are available.

\begin{tabular}{|l|l|l|c|c|c|}
\hline \multirow{2}{*}{ Element } & \multicolumn{2}{|c|}{ Study Owls } & \multicolumn{2}{c|}{ ERICA Tool 'Birds' } \\
\cline { 2 - 6 } & $\mathbf{n}$ & $\begin{array}{l}\text { Concentration ratio } \\
\mathbf{C R}_{\text {wo-soil }} \pm \text { SD }^{\#}\end{array}$ & $\begin{array}{c}\text { Concentration ratio } \\
\text { CR }_{\text {Wo-soil }} \pm \text { SD (if applicable) }\end{array}$ & $\begin{array}{c}\text { Source of data in } \\
\text { ERICA Tool }\end{array}$ \\
\hline $\mathrm{Co}^{*}$ & 5 & $1.1 \times 10^{-3} \pm 1.0 \times 10^{-3}$ & $3.0 \times 10^{-1}$ & 29 & Uses mammal \\
\hline${ }^{137} \mathrm{Cs}^{*}$ & 5 & $2.6 \times 10^{-2} \pm 1.6 \times 10^{-2}$ & $7.5 \times 10^{-1} \pm 1.6$ & 158 & Literature review \\
\hline $\mathrm{Fe}$ & 5 & $2.2 \times 10^{-3} \pm 1.2 \times 10^{-3}$ & - & - & no data available \\
\hline $\mathrm{Rb}$ & 5 & $9.6 \times 10^{-2} \pm 5.9 \times 10^{-2}$ & - & - & no data available \\
\hline $\mathrm{Sc}^{*}$ & 5 & $2.6 \times 10^{-4} \pm 1.3 \times 10^{-4}$ & - & - & no data available \\
\hline $\mathrm{Zn}$ & 5 & $2.4 \times 10^{-1} \pm 1.4 \times 10^{-1}$ & - & - & no data available \\
\hline
\end{tabular}

*Includes some data below detection limits, see text. "Standard deviation takes account of the error for both the carcass and liver samples.

The mean concentrations of $\mathrm{Rb}$ and $\mathrm{Zn}$ were similar in the liver and carcass whereas the liver concentrations were higher than the carcass for Fe (3.5 fold) and for Co (4 fold) which is consistent with the ability of liver to accumulate heavy metals [4]. For Sc the carcass concentrations were an order of magnitude higher than those in the liver which is in agreement with data on Sc distribution (in rats) [5]. As there were a limited number of samples available for this scoping study the one Tawny owl and two Barn owl chicks were included in the data summaries with the two adult Barn owls; there are insufficient data to identify any trends for any elements according to species or age.

\subsection{Gamma analysis}

All samples were analysed for 2-4 days. The only anthropogenic radionuclide measured in the owl samples was ${ }^{137} \mathrm{Cs}$ and this was only measurable in two owl carcass samples (one adult Tawny and one adult Barn owl) at 1.17 and $0.39 \mathrm{~Bq} \mathrm{~kg}^{-1}$ (fresh weight). Measurements were below detection limits for the three other owl carcasses so a value of $50 \%$ of the detection limit was used to calculate the mean values for the group. Concentrations of ${ }^{137} \mathrm{Cs}$ measured in the 20 soil samples ranged from 7.5-51.3 $\mathrm{Bq} \mathrm{kg}^{-1}$ (dry weight).

\subsection{Concentration ratios}

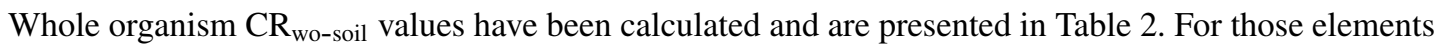
measured by neutron activation analysis, the $\mathrm{CR}_{\mathrm{wo} \text {-soil }}$ values were calculated by dividing the mean whole body element concentrations in $\mathrm{mg} \mathrm{kg}^{-1}$ (fw) by the respective mean soil element concentrations in $\mathrm{mg} \mathrm{kg}^{-1}(\mathrm{dw})$. Cobalt and scandium were not detectable in two of the carcass samples and scandium 
was also not detectable in three of the liver samples, therefore the $\mathrm{CR}_{\mathrm{wo} \text {-soil }}$ values derived here for these elements include data below detection limits (values were halved prior to calculation of the arithmetic mean). Cs-137 $\mathrm{CR}_{\mathrm{wo} \text {-soil }}$ values were calculated from the activity concentrations measured in the carcass only in $\mathrm{Bq} \mathrm{kg}^{-1}$ (fw) and the respective mean soil activity concentration measured in $\mathrm{Bq} \mathrm{kg}^{-1}$ (dw); this was considered valid as $\mathrm{Cs}$ is known to be relatively uniformly distributed in soft tissue.

The current default $\mathrm{CR}_{\text {wo-soil }}$ values in the ERICA Tool $[6,7]$ relevant to this study are compared with those values derived here in Table 2. CR values for birds within the ERICA Tool database obtained from literature reviews are available for $\mathrm{Cs}, \mathrm{Pb}, \mathrm{Ra}, \mathrm{Ra}, \mathrm{Sr}, \mathrm{Tc}$, Th and $\mathrm{U}$. Of these elements only $\mathrm{Cs}$, $\mathrm{Ra}$ and $\mathrm{Sr}$ include (very limited) data for predatory birds. We are not aware of other $\mathrm{CR}_{\mathrm{wo} \text {-soil }}$ data for birds for $\mathrm{Co}, \mathrm{Fe}, \mathrm{Rb}, \mathrm{Sc}$ and $\mathrm{Zn}$.

The Co $\mathrm{CR}_{\mathrm{wo} \text {-soil }}$ value for owls was considerably lower than the mammal $\mathrm{CR}_{\mathrm{wo} \text {-soil }}$ value currently used in the absence of other data for birds in the database underlying the ERICA Tool. It is also lower than the minimum mammal $\mathrm{CR}_{\mathrm{wo} \text {-soil }}$ value reported in [7] of $5.9 \times 10^{-2}$ which is data for roof rats (Rattus rattus) from a terrestrial community at Enewatak Atoll [8]. The ${ }^{137} \mathrm{Cs}_{\mathrm{CR}} \mathrm{R}_{\mathrm{wo} \text {-soil }}$ value for the owls is lower than the default mean $\mathrm{CR}_{\mathrm{wo}}$ value in ERICA Tool (see Table 2) and at the low end of the reported range $\left(1.4 \times 10^{-3}-1.6 \times 10^{1}\right)$. However, the owl $\mathrm{CR}_{\text {wo-soil values for }}{ }^{137} \mathrm{Cs}$ are in good agreement with the few $\mathrm{CR}_{\mathrm{wo} \text {-soil }}$ values for predatory birds within the ERICA Tool database - a Goshawk (Accipiter gentili) $\left(\mathrm{CR}_{\mathrm{wo} \text {-soil }}=9 \times 10^{-2}\right)$, a Harrier (Circus spp. $)\left(\mathrm{CR}_{\mathrm{wo}-\text { soil }}=1 \times 10^{-1}\right)$ and a White tailed eagle (Haliaeetus albicilla) $\left(\mathrm{CR}_{\mathrm{wo}-\text {-soil }}=8 \times 10^{-3}\right)$ all from the Chernobyl exclusion zone.

The forthcoming IAEA handbook on transfer parameters for wildlife [1] will not greatly improve the availability of $\mathrm{CR}_{\mathrm{wo} \text {-soil }}$ values for birds compared with that complied for the ERICA Tool [7]. The draft handbook contains no values for $\mathrm{Co}, \mathrm{Fe}, \mathrm{Rb}$, or Sc. The number of data available for $\mathrm{Cs}$ has slightly increased (to $\mathrm{n}=180$ ) compared to that underlying the ERICA Tool database and the $\mathrm{CR}_{\mathrm{wo} \text {-soil }}$ in the draft handbook is also similar $\left(6.7 \times 10^{-1}\right)$. The ${ }^{137} \mathrm{Cs}_{\mathrm{CR}_{\mathrm{wo}-\text { soil }}}$ values derived here for owls (see

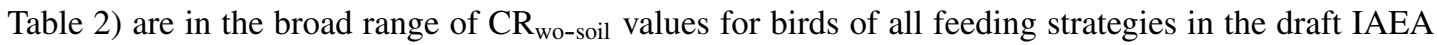
handbook $\left(1.4 \times 10^{-3}-1.6 \times 10^{1}\right)$. Currently there are insufficient Cs values in the database used to produce the IAEA handbook to enable a $\mathrm{CR}_{\text {wo-soil }}$ to be recommended specifically for carnivorous bird species.

Although a relatively small number of samples have been analysed, the work presented here demonstrates the potential for sample archives to be exploited to derive $\mathrm{CR}_{\mathrm{wo} \text {-media }}$ values for the many required organism-radionuclide combinations for which there are currently few, or no, data. Increasingly approaches such as NAA and ICP-MS analyses are being used to cost effectively determine a large number of relevant elements in samples from which $\mathrm{CR}_{\mathrm{wo}-\text { media }}$ values can be derived. However, there may be some need to consider how representative stable element data are for radiological assessments. The transfer of radionuclides with short physical half-lives, especially those with comparatively long biological half-lives is probably likely to be overestimated using stable element data. Conversely, the source of a stable element in soil (e.g. from geological material) versus that of the radioisotope may result in a lack of isotopic exchange and equilibrium between the radionuclide and its stable element, probably resulting in an underestimate of radionuclide transfer. However, previous studies have demonstrated that stable Cs can be used as an analogue for ${ }^{137} \mathrm{Cs}$ to derive transfer parameters [9].

There is some difficulty, as with all animals with a large home range, in taking representative soil samples associated with each bird. This is a potential source of uncertainty in the work described above. In future, consideration should be given to using available spatial soil concentration databases (e.g. [10]) in association with targeted sampling.

\section{References}

[1] Howard, B.J., Beresford, N.A., Copplestone, D., Telleria, D., Proehl, G., Fesenko, S., Jeffree, R., Yankovich, T., Brown, J., Higley, K., Johansen, M., Mulye, H., Vandenhove, H., Gashchak, S., Wood, M., Takata, H., Anderson, P., Dale, P., Ryan, J., Bollhöfer, A., Doering, C., Barnett, 
C.L., Wells, C. (2011). A new IAEA Technical Report Series handbook on radionuclide transfer to wildlife. These proceedings.

[2] Taylor, I. (1994). Barn Owls - Predator prey relationships and conservation. Cambridge University Press, Cambridge.

[3] Oughton, D.H., Salbu, B. (1992). Stable caesium, rubidium and potassium distribution with reference to radiocaesium metabolism studies. Radiat. Prot. Dosim., 41, 217-222.

[4] Furness, R.W. (1993). Birds as monitors of pollutants. In: Furness, R.W. and Greenwood, J.J.D. (Eds.). Birds as monitors of environmental change. Chapman and Hall, London, pp 86-143.

[5] Hathcock, N., Hill, C.H., Matrone, G. (1964). Vanadium toxicity and distribution in chicks and rats. J. Nutr., 82, 106-110.

[6] Brown, J., Alfonso, B., Avila, R., Beresford, N.A., Copplestone, D., Pröhl, G., Ulanovsky, A. (2008). The ERICA Tool. J. Environ. Radioact., 99, 1371-1383 Barraclough, D. (2007). UK Soil and Herbage Survey (UKSHS). Report no. 1. Introduction and summary. Environment Agency, Bristol.

[7] Beresford, N.A., Barnett, C.L., Howard, B.J., Scott, W.A., Brown, J.E., Copplestone, D. (2008). Derivation of transfer parameters for use within the ERICA Tool and the default concentration ratios for terrestrial biota. J. Environ. Radioact., 99, 1393-1407.

[8] Bastian, R.K., Jackson, W.B. (1975). Cs-137 and Co-60 in a terrestrial community at Enewatak Atoll. Proceedings of a symposium on radioecology and energy resources. C. E. J. Cushing. London, Academic. pp 313-320.

[9] Tagami, K., Uchida, S. (2010). Can elemental composition data of crop leaves be used to estimate radionuclide transfer to tree leaves? Radiat. Environ. Biophys., 49, 4, 583-590.

[10] Barraclough, D. (2007). UK Soil and Herbage Survey (UKSHS). Report no. 1. Introduction and summary. Environment Agency, Bristol. 